\title{
Green Militarization and the Necessity of Local Involvement
}

\section{SOPHIA FOSTER*}

\begin{abstract}
This article argues that Green Militarization, the use of military and paramilitary actors in the pursuit of conservation (Lunstrum, 2014), is most effective with the involvement of local communities as one instrument in combating environmental issues. The arguments used to demonstrate this emphasize the great dependence humans have on endangered species and their environment, the aid locals can provide to conservation operations, and the risk of human settlements being encroached if conservation is effective without local involvement. This paper will offer examples of effective conservation programs in West Bengal and Nepal. Militarized conservation programs based on the ideas of coexistence and respect of all species not only benefit the region and its non-human species, but also lead to improved human conditions.
\end{abstract}

Keywords: Conservation; green militarization; coexistence; local involvement; environmental degradation; endangered species; anthropocene; security.
Résumé - Cet article soutient que la militarisation verte, l'utilisation d'acteurs militaires et paramilitaires dans la poursuite de la conservation (Lunstrum, 2014), est plus efficace lorsqu'elle implique les communautés locales en tant qu'instrument de lutte contre les défis environnementaux. Les arguments utilisés pour démontrer cette affirmation mettent en évidence la grande dépendance des humains vis-à-vis les espèces menacées et leur environnement, l'aide que les populations locales peuvent apporter aux opérations de conservation et le risque que les établissements humains soient affectés si la conservation est efficace en l'absence de participation locale. Cet article offrira des exemples de programmes de conservation efficaces au Bengale-Occidental et au Népal. Les programmes de conservation militarisés fondés sur les idées de la coexistence et du respect de toutes les espèces profitent non seulement à la région et à ses espèces non humaines, mais mènent également à de meilleures conditions humaines.

Mots-clés : Conservation; militarisation verte; coexistence; participation locale; dégradation de l'environnement; espèces en voie de disparition; anthropocène; sécurité.

Sophia Foster is a fourth-year Undergraduate student attending the University of Ottawa for Conflict Studies and Human Rights. During her four-year degree she conducted research at the Human Rights Research and Education Center at the University. Here, she aided the UN Special Rapporteur on the Independence of Judges and Lawyers, Diego Garcia-Sayan, in drafting and researching for his published reports.

Sophia Foster est une étudiante de premier cycle. Elle complète actuellement un baccalauréat en études des conflits et droits humains offert par l'Université d'Ottawa. Pendant ses quatre années d'études, elle a mené des recherches au Centre de recherche et d'enseignement sur les droits de la personne de l'Université d'Ottawa. Dans le cadre de son travail au Centre, elle a assisté le rapporteur spécial des Nations Unies sur l'indépendance des juges et des avocats, Diego Garcia-Sayan, dans la rédaction et dans la recherche appuyant ses rapports publiés. 


\section{Introduction}

The world is currently facing negative effects of climate change, including a rise in extinction and ecosystem destruction. To put biodiversity loss into perspective, "human activity has increased the extinction rate by at least 100 times compared to the natural rate" (Biodiversity, n.d.). With a decline in biodiversity, humans are exposed to food insecurity, vulnerability to natural disasters, energy insecurity, and a lack of access to clean water; as a result of these exposures, security scholars explore and critique the techniques used to combat and prevent climate change's negative impacts. Conservation is an important means to protect species threatened by climate change. Green Militarization is a method of conservation using military and paramilitary actors, techniques, technologies, and partnerships (Lunstrum, 2014). National armies play a key role in conservation programs in countries such as Guatemala, Columbia, Nepal, Indonesia, South Africa and Botswana (Lunstrum, 2014). The relationship between conservation and military is not new but has experienced a major shift in its history. Changes in militarized conservation programs have been attributed to technological advancements, as well as a rise in participatory approaches with the direct involvement of human communities. Large investments have been made in the field of Green Militarization: the European Commission provided over 30 million euros to the Virunga National Park in the Democratic Republic of Congo from 1988 to 2015 (Marijnen, 2017); the United States government granted US\$24 million to fund a "global system of regional wildlife enforcement networks" in South Africa; and Google donated US\$5 million to the World Wildlife Fund for surveillance drones in sites of commercialized poaching (Lunstrum, 2014).

\section{Basis for Local Involvement in Green Militarization}

Acknowledged by few scholars, there is a lack of research on the effectiveness of Green Militarization, what makes it successful, and how it impacts surrounding human settlements. This paper argues that Green Militarization, whether or not it is better than any other conservation method, can only be effective with the support of local human communities. The argument in favour of military involvement in conservation emerges from the concept of the state monopoly over violence; "the state alone has the right to use or authorize the use of physical force" (Munro, 2013). Poaching is an ungoverned form of violence against the state's natural resources and therefore a state solution through the use of military is a consistent means to combat poaching. The following paper will outline the methods and evidence to show that local involvement is necessary for Green Militarization to be successful. First the article will discuss how local populations are the most dependent on conservation territory, how military units and locals can work together effectively, as well as the consequences of Green Militarization programs without local populations' involvement. Next, the paper will offer an explanation of a theoretical framework based on First Nations' thought, followed by a literature review, a case study on Nepal and West Bengal, and a personal analysis on militarized conservation.

In the case of conservation programs failing, the surrounding human communities are one of the main actors negatively affected. Locals can face high levels of insecurity including unemployment, food insecurity, and possible forced migration. The dependence local communities have on their environment can be illustrated by the benefits they receive when successful conservation programs are implemented. Bajracharya et al. (2008) noted institutional and infrastructure development, improved water resources, as well as higher levels of health and sanitation in various projects around the world. In terms of employment opportunities, locals have observed the emergence of ecotourism, including safaris, tours or hotels. Thapa et al. (2013) report that new forms of ecotourism promote investment into conservation strategies as well as encourage the locals to support the programs in the region; the support comes from the economic opportunities the tourists bring to the region, leading to higher employment opportunities and growth in the economy. It should be noted that surrounding populations do not always encourage conservation programs in order to stabilize biodiversity but perhaps to secure economic or political objectives (Chicchon, 2000). The point of conservation should be focused on creating societies that are stable in coexistence, leading to the recognition of all actors' objectives. Human settlements are extremely reliant on their natural environment and this is illustrated by the large impact successful conservation programs have on societies.

In general, the more dependence a community has on something the more they will want to protect it. Kharel and Fanindra Raj (2012, p. 27) state that locals know that "overexploitation, poaching and illegal collection 
of any taxa will ultimately threaten its survival." Humans are dependent on the environment in which they live and in recognizing this, we will ultimately become more secure. Chicchon (2000, p. 1368) recognizes the importance conservation plays in locals' security stating that "rural peoples are and should be allies of biodiversity conservation not only because it is a basic human right but because they are the ones who have the most to lose if the resources they depend on are depleted." By observing the intertwined securities that exist in conservation programs, it is clear that a secure environment results in healthier and more stable human communities. All species intensely rely on their local environments for security; so, human settlements should be considered main actors in any local projects based on environmental protection. Because of interconnected dependencies participatory militarized conservation projects can improve the lives of multiple species, simultaneously. To further the argument of humans needing to recognize their dependence on the environment and other species, we need to question what will happen without this awareness. It may be that a Green Militarization program is effective in a specific region, but what will happen if the region's human population continues to disrespect local endangered species? The species may increase but due to the lack of appreciation from the local human population, it is very likely that the endangered species' population will decrease repeatedly. Involvement of the local community is crucial due to the large impact their lack of consideration of endangered species can have on the vulnerable group's rejuvenation.

In most Green Militarization programs, the parks are patrolled by humans armed with guns, searchlights, and radio systems (Martin, 2006). The parks are guarded 24 hours a day, 7 days a week, with the intensity of a military mission. Although the direct military protection could instill fear in poachers, deterring them from any illegal activity, poaching persists in areas lacking local support. Local involvement can take many different forms including offering intelligence, voluntary patrolling of protected areas, and actual employment. Because of the amount local communities have at stake in protecting their environment, Green Militarization receives a large amount of assistance from the residents. The first feature that local communities offer military units is intelligence. Martin (2006) states that "local people around the park appreciate the department's activities for the community and will thus report potential rhino poachers entering Gorumara." In this specific region, Martin (2006) also claims that rhino poaching has been completely eliminated because of the locals' freely given intelligence. Acharya and Kandel (2012) offer the analogy that the "communities are acting as watch dogs for law enforcements processes and moral supports to enforcement authorities." Due to the locals' intelligence, the deaths of endangered species or the exploitation of resources can be prevented, due to early arrests and stable security.

The second component that locals offer militarized conservation units is watching the exterior of the protected areas voluntarily. Although the locals do not gain any financial compensation for their work, individuals will act as patrollers in order to help the military units (Martin, 2006). This leads to further protection as they have workers on the inside and volunteers on the outside working hard in order to safeguard the park. While the locals patrol the protected areas, they offer aid in removing any traps, turning over illegal firearms as well as facilitating operations against poachers (Acharya \& Kandel, 2012). The act of locals patrolling leads to greater amounts of individuals protecting the park, helping to increase endangered species' populations and reduce any exploitation of resources in the territory. Without the help of locals, Green Military operations would be ineffective in gathering intelligence on local criminals, dismantling traps where the animals roam outside of the protected areas, as well as having large numbers of employees.

Another factor of conservation that needs to be recognized is the growth and expansion that appears if the program is successful. Once a species' population experiences an increase in numbers, the amount of territory and resources that are needed also rise. The perspective and involvement of local communities is thereby crucial because species will expand into the surrounding human-dominated territory. If the conservation in a specific area is successful, the surrounding human populations can experience livestock depredation, crop damage and physical injuries from the increasing populations of megafauna (Bajracharya et al., 2008). Because of the need to protect endangered species, the local communities need to understand the complexity of coexistence. Bajracharya et al. (2008) as well as Thapa et al. (2013) recognize compensation as the easiest way to reduce conflict between human and the protected species. The disturbances that can appear from the expansion of conservation projects need to be prepared for. Any damage that the communities experience should be paid for, alleviating any harm done to individuals, crops or livestock. Thapa et al. (2013) suggest an "incentive structure associated with the conservation," leveling out the cost-benefit ratio of having a conservation program close to human settlements. Another option is 
to allow the locals greater access to the parks resources. By granting locals access to the park, it promotes greater coexistence and support of the projects. Some of the incentives that can be offered to the local settlements include thatch grass collection, providing dead woods free of cost, conservation education and a buffer zone program (Kharel et al., 2012). All four of these incentives allow the local community greater involvement as well as understanding of the militarized conservation. By advocating for their engagement, locals will appreciate and respect the project, leading to more involvement and support. Local human settlements are affected by conservation projects and by recognizing and preparing for this through compensation and greater access to resources, there will be more involvement, work and support that the locals give to the project.

\section{Theoretical Framework}

The theory used in the following paper comes from the teachings of the Canadian First Nations. These teachings have been passed on for hundreds of years and were discredited during colonization. Not only do they allow for a conservation method centered on local populations but they also acknowledge the interdependence humans have on their surroundings. Canada has diverse Indigenous groups and it is important to recognize that worldviews across Indigenous groups are varied. In a process of reconciliation and healing with Canadian Indigenous peoples, it is important to acknowledge how valuable these ideas are, and how they should be adopted in a connection to the environment; Indigenous beliefs should not be exploited but shared in an appropriate manner.

Although Indigenous worldviews vary across Canada, a core principle of many groups is the idea of interconnectedness. Because of this interconnectedness, humans are not meant to dominate all other species but act as a part of "the Great Sacred Circle - the circle of relationships" (Abel, Sioui, \& Brierley, 2000). Many Indigenous circle societies in Canada recognized the "fundamental and sacred unity of all things created" (Abel et al., 2000). A growing idea is that of the Medicine Wheel which "represents harmony and connections and is considered a major symbol of peaceful interaction among all living beings on Earth" (Native American Medicine Wheel, n.d.). A large part of the Medicine Wheel idea comes from the circular structures found in Earth's natural environment. The circular structure of the wheel can be found in the changing of seasons, the spinning of the Earth, and the dependence each species has on one another. This symbol is used by some Indigenous peoples to display a "cyclical nature of all relationships and interactions," recognizing that "Everything in the universe is part of a single whole" (Native American Medicine Wheel, n.d.). In a relational context the Medicine Wheel believes that there are consequences for every action and in understanding these repercussions humans can care for their surroundings better (Wenger, 2010). In separating communities (human or non-human), a disruption occurs in the balance of the circle and all beings involved are affected (Wenger, 2010).

Adopting these teachings in the conversation of how to protect other species allows for a disengagement from an anthropocentric perspective. It should not be possible to talk about the protection of other species while viewing the world centered on humans. Using the Medicine Wheel and Cyclical beliefs of some First Nations peoples allows for a focus on balance, coexistence and responsibility. Transferring these teachings to a discussion on conservation instructs humans to respect the rights of all beings while recognizing the importance of diversity. The First Nations teach of the large impact species have on one another, obligating humans to protect and act in respect of other species.

\section{Literature Review}

The literature on the topic of Green Militarization is very contested due to the lack of research and unclear findings. All of the articles surveyed call for an increase in research and most scholars, including Duffy (2014) and Lunstrum (2014), agree that the current findings are unclear. However, even without a large amount of research completed, some scholars do not believe Green Militarization is an effective form of conservation (Duffy, 2014; Marijnen \& Verweijen, 2016). It is argued that this type of conservation does not directly fight the underlying causes of resource depletion and poaching, such as international trade systems and wildlife commodification, resulting in the discrediting of the field. Specifically, Lunstrum (2014), as well as Duffy (2014) give an introduction to Green Militarization: its justifications, consequences and its role in national and global institutions. Marijnen (2017) as well as Marijnen and Verweijen (2016) discuss the business of Green Militarization, in terms of the role of 
development aid and marketization in the specific case of the Democratic Republic of Congo. Khagram and Ali (2006), Duffy (2016), Douglas and Alie (2014) look at the connection between conservation and security. Khagram and Ali (2006) argue that the role of environmental conservation should be to promote peace, whereas Duffy (2016) critiques the field of Green Militarization by arguing that counterinsurgency and security are becoming integrated.

Green Militarization should continue to be researched, but with a focus on involvement of local communities in militarized conservation. The important gap that the scholars previously mentioned did not discuss is the role surrounding communities can play in these projects. Kharel (2012), Martin (2006), Bajracharya et al. (2008), as well as Thapa et al. (2013) look at the successes of Green Militarization in Nepal and the role local populations had in achieving that success. Following, Acharya and Kandel (2012) and Chicchon (2000) offer realistic roles that locals can have in militarized conservation, such as patrolling and offering intelligence. This paper will fill gaps in the current literature by incorporating a holistic theoretical framework that takes into account the impacts of involvement on the community itself, and the necessity of a societal shift in surrounding human settlements. Whether Green Militarization is the best form of conservation or not, this paper will argue that militarized conservation can only be successful with the involvement of surrounding human communities. The definition of success in a Green Militarization context is found in this paper's Theoretical Framework: building societies and conservation programs assembled on coexistence and alliance, furthering the recognition of each actors' objectives.

Local involvement in Green Militarization can help address many of the critiques found in the literature. One of the main critiques that have been made in regards to militarized conservation is that scholars believe it is dangerous to militarize the conversation on biodiversity. Duffy (2014) found that $90 \%$ of major armed conflicts have taken place in countries that contain biodiversity hotspots. Because of this, she questions whether conservation should also become a place of war when there are already high chances of conflict appearing. Duffy (2014) explains that she believes it is problematic to intersect conservation with war and conflict. An example she offers is the use of the political norm of Responsibility to Protect (R2P). This term appeared in the early 2000s and mainly refers to humanitarian intervention, encouraging states to intervene when evidence of human rights violations appear. As an example of international intervention in the form of conservation, foreign mercenaries have been utilized in conservation programs such as French mercenaries in the Central African Republic protecting elephant populations (Lunstrum, 2014). Similar to the questions of intervention to save human lives, R2P can become problematic in conservation because it is unclear which species and resources should be seen as needing intervention and whether or not conservation should be militarized. Duffy problematizes the use of R2P as she believes actors "enter into conservation areas willing to engage in deadly force, and what follows is an inevitable cycle of militarization" (Duffy, 2014). It is clear that militarized conservation alone does not bring an end to poaching and so violence continues to appear. Also, in maintaining a Medicine Wheel mindset R2P is an invalid reasoning for Green Militarization due to its promotion of human exceptionalism. There needs to be a societal shift on the importance of biodiversity and the protection of resources, rather than a simple military solution. Without a change in the way humans live, sustainability and coexistence cannot appear. The Indigenous Medicine Wheel, as a theoretical framework, furthers this argument as it is a way of life for circle societies, not only a strategy of control over violence.

As a further critique, Green Militarization creates a binary of poacher versus ranger (Duffy, 2014; Marijnen, 2017). The poacher is viewed as a secretive and evil actor, whereas the ranger is seen as a protector and hero. Duffy (2014) believes that because of the creation of a simple image of an evil poacher, a military approach is seen as a necessity in order to combat a secretive and unknown actor. She discusses the use of a shoot-to-kill tactic where the heavily armed poacher is killed on site. The life of the poacher is seen as unimportant because of the negative images that surround them. It is important to recognize that situations are much more complex than a simple binary. For instance, a person may become a poacher in order to feed their family, send their child to school, etc. There is not simplicity in the image of an individual and in order to support military operations, the recognition of individual agency is a necessity (Marijnen, 2017). Duffy (2014) offers the shoot-to-kill tactic as an example where it is not used as a defence mechanism but as a preventive measure in the face of the death of an endangered animal. In this sort of scenario, it should be noted that the poacher that is murdered has their own life and story. Perhaps their murder now leaves an entire family behind without economic security. This topic is extremely complex and Duffy 
is accurate in critiquing this binary. Fortunately, with the involvement of local communities in conservation programs there would be stronger economic stability resulting in less of a necessity to poach. Local communities would also aid in preventing a shoot-to-kill scenario from ever happening with their help in providing intelligence and patrolling. The locals help to create preventive measures and the shoot-to-kill mechanism would be a last resort. The ensuing paper will offer a case study, followed by an analysis.

\section{Case Study of Nepal and West Bengal}

Nepal and West Bengal have been recognized as some of the most successful forms of militarized conservation, exemplifying coexistence and the involvement of local populations. Offering the case study of Nepal and West Bengal allows an analysis on the effective protection of resources and species, followed by the benefits local communities have experienced from the conservation programs.

West Bengal has experienced a gradual increase in rhino population since the introduction of local involvement in their militarized conservation; a rhino has not been poached since 1996 and the numbers have risen from a low of 26 to over 100 in 2006 (Martin, 2006), with recent numbers suggesting a population of 250 (Singh, 2015). Although other forms of poaching exist in the area, rhino poaching has been eliminated in the park of Gorumara. Most of the success in eliminating rhino-poaching has been due to the intelligence offered by local communities (Martin, 2006). Due to the large importance the conservation program plays in the stability of the locals' livelihoods, they help in any way that they can. In the specific part of Gorumara in Bengal, the tactics of patrol, compensation to villagers for wildlife damage, and intelligence from the locals are directly linked to the success of their wildlife protection. Although the military units work hard in protecting the area, the locals and employers of the territory also work together in order to eliminate illegal activity (Martin, 2006).

In the specific case of Nepal, Kharel et al. (2012, p. 28) recognize that the "anti-poaching units are mainly successful due to the involvement of local communities." Nepal began rhino anti-poaching tactics when the beginning of democracy appeared in the country in the 1950s with the initiation of several programmes including translocations of rhinos, armies with as many as 130 armed men, and the creation of sanctuaries (Thapa et al., 2013). By the late 1960s the rhino population had declined to below 100, creating an extremely threatened species even with the appearance of militarized conservation. With the population still vulnerable the Department of National Parks and Wildlife Conservation created a nationwide programme in 2007 with the goal of gaining a political commitment to the protection of the species: Operation Unicornis (Thapa et al., 2013). Operation Unicornis allowed for a community-based intelligence network, projects centered on "community stewardship," as well as the creation of "community-led anti-poaching teams" (Thapa et al., 2013). In the specific case of Nepal, "community stewardship" appeared through forestry projects which allowed locals to ecologically restore the corridors inhabited by the protected rhinos (Thapa et al., 2013). Thapa et al. (2013) state that "During the 5 years since the communityled anti-poaching units were established to patrol, and to protect wildlife in the corridors, there has been no evidence of poaching of rhinoceroses in the Khata and Laljhadi corridors, despite heavy poaching in the protected areas." The protected areas have also experienced a reduction in the depletion of natural resources, a regeneration of trees on degraded land and increased wildlife (Bajracharya et al., 2008). Fortunately, the surrounding human settlements have also benefited with a study finding that $78 \%$ of local residents surveyed reported that "basic infrastructure such as drinking water, trails, bridges and health facilities had improved following the conservation intervention"; $81.6 \%$ also reported the belief that economic opportunities had increased in the community (Bajracharya et al., 2008). Although livestock depredation was found to be an issue involved in these conservation tactics, it was found that $64-66 \%$ of local populations did not view livestock depredation as a serious issue (Bajracharya et al., 2008). The case of Nepal allows for an analysis of the effectiveness of Green Militarization before and after the involvement of the local community.

For both cases, it is important to understand the role of the poachers in relation to local communities. Even if a poacher is killed as a last resort in militarized conservation areas, their death could lead to distrust, and a decrease in local support of the conservation program (Lunstrum, 2014). In this sort of scenario, the military operation will then lose access to intelligence and voluntary troops on the ground. This emphasizes the importance that these conservation programs play in the life of the surrounding community. Fortunately, if the community lays great 
importance on the species or resources, as displayed through the case studies of Nepal and West Bengal, individuals will not want to jeopardize the conservation project with poaching or resource exploitation; decreasing the potential of locals being killed in the protected areas. Clearly, the case studies of Nepal and West Bengal display the benefits biodiversity and human societies experience from participatory militarization conservation.

\section{Alternative Perspectives on Conservation Policies}

The Indigenous Medicine Wheel offers an interesting perspective on conservation because it creates a disconnect from the mainstream idea that humans are superior to non-human animals. The Medicine Wheel allows for a form of conservation built on coexistence, teamwork and tolerance. Humans are one actor in a much larger ecosystem and this point needs to be reiterated. In terms of coexistence, humans should dismantle their paternalistic strategy of conservation and act as a partner and ally to endangered species. By involving military operations in the conservation dialogue, we are encouraging humans to fight for biodiversity and environmental stability, advocating for work away from an anthropocentric mindset. I found that scholars questioned whether or not humans should risk their lives for other species. Similar to Green Militarization, humanitarian intervention asks whether or not some citizens should risk their lives for other citizens. I believe that this hierarchy should not exist. Of course, restrictions are crucial in the dialogue of intervention but as humans we have a responsibility to guard the land that we have previously destroyed as exemplified by the examples of West Bengal and Nepal. On the other hand, R2P is important to discuss because states can act out of their own self-interest in the name of humanitarian intervention or Green Militarization. International actors can encourage militarized conservation in order to gain access to resources, such as oil. Comparable to humanitarian intervention, these international interests need to be recognized and combated with the involvement of local communities. Although local actors can also act out of self-interest, as mentioned earlier, they also hold a high level of dependence on the resources. As a result, even if they act out of self-interest, their survival is dependent on the health of the environment; giving them a much higher level of responsibility.

Studying West Bengal and Nepal confirmed the amount of work local communities do in their regional conservation projects. This work included patrolling, offering intelligence as well as acting as "watch dogs" for law enforcement. I believe that part of the reason Green Militarization does not work without community support is because in order to make drastic changes, societal changes are needed. In these specific scenarios, the locals were able to collaborate with the military while offering support to the conservation programs. By appreciating and taking part in this process, locals gained an even stronger tie to their surrounding environment.

The Indigenous Medicine Wheel as well as modern-day social justice movements justify why humans should act as an ally to endangered species. Movements centered on the elimination of distinctions between humans (i.e., racism, sexism, ableism), combined with Medicine Wheel and cyclical knowledge enforce the need for further empathy between groups unknown to each other. Exemplified by the Universal Declaration of Human Rights, UN member states recognized the importance of equality and liberty, connecting to the Medicine Wheel's traits of interdependence and coexistence. With modern-day social justice movements finally recognizing the importance of all humans, the Medicine Wheel's teachings argue for the recognition of all species. Different humans offer different things; just as diverse species offer different things to the world. Humans often forget that they are animals as well and as history has taught us time and time again, one group ruling over all others simply does not work. Conservation and the involvement of locals in protecting endangered species asks humans to reassess our current involvement in the lives of other species.

\section{Conclusion}

In this paper I have argued that Green Militarization can only be effective with the support and involvement of surrounding human settlements. More research on environmental sociology is crucial in the context of Green Militarization. How does local environmental sociology change with the implementation of militarized conservation? Do residents only recognize the necessity of a healthy environment in regards to their own survival or do they generally change their mindset to become more appreciative of the environment? Additional research could include analyzing their use of language, artistic communities and cultural ceremonies that display elements of 
environmental sociology. This paper first recognized that locals were the actors most affected by instability in the environmental region. Locals depend on these specific areas for basic needs such as food and water, as well as income and employment. With a decline in the ecosystem's health, the appearance of insecurity also appears in the human settlements. Next, I displayed the effectiveness of local involvement in patrolling and guarding specific areas. Finally, I explained that if Green Militarization were to be successful on its own, the resources and megafauna would expand and roam into the human settlements leading to unwanted conflict. In order to prevent and prepare for these scenarios, a strong relationship between the locals and military unit is a necessity.

The definition of security continues to be broadened with an emphasis now being placed on protecting ourselves from the consequences of climate change appearing in the form of mass extinction, resource depletion, loss of biodiversity, etc. In order to combat these types of issues, we need to have strong and effective conservation strategies. As an approach to issues caused by climate change, the shift and increasing use of Green Militarization needs to be analyzed. In the future, local involvement needs to be highlighted in militarized conservation programs in order to combat the elimination of megafauna and essential resources, which is crucial to the security of human and non-human species alike. 


\section{References}

Abel, K., Sioui, G. E., \& Brierley, J. (2000). Huron-Wendat: The heritage of the circle. The Michigan Historical Review, 26(2), 16-31, 112-115.

Acharya, K., \& Kandel, P. (2012). Controlling wildlife crime in Nepal: Sharing experiences. Biodiversity conservation in Nepal: A success story (pp. 45-69). Department of National Parks and Wildlife Conservation, Babar Mahal, Kathmandu. Retrieved from https://www.researchgate.net/publication/272354436_biodiversity_conservation_in_nepal_a_success_story

Bajracharya, S., Furley, P. A., \& Newton, A. C. (2008). Impacts of community-based conservation on local communities in the Annapurna Conservation Area, Nepal. In D.L. Hawksworth \& A. T. Bull (Eds.), Human Exploitation and Biodiversity Conservation (pp. 425-446). Springer.

Biodiversity \& Human Well-being. (n.d.). Retrieved 22 February 2018 from http://www.greenfacts.org/en/biodiversity/

Bray, D. B., Merino-Perez, L., Negreros-Castillo, P., Segura-Warnholtz, G., Torres-Rojo, J. M., \& Vester, H. F. (2003). Mexico's community-managed forests as a global model for sustainable landscapes. Conservation Biology, 17(3), 672-677.

Chicchon, A. (2000). Conservation theory meets practice. Conservation Biology, 14(5), 1368-1369.

Douglas, L. R., \& Alie, K. (2014). High-value natural resources: Linking wildlife conservation to international conflict, insecurity, and development concerns. Biological Conservation, 171, 270-277.

Duffy, R. (2014). Waging a war to save biodiversity: The rise of militarized conservation. International Affairs, 90(4), 819-834. doi:10.1111/1468-2346.12142

Duffy, R. (2016). War, by conservation. Geoforum, 69, 238-248. doi:10.1016/j.geoforum.2015.09.014

Hammill, E., Tulloch, A. I. T., Possingham, H. P., Strange, N., \& Wilson, K. A. (2016). Factoring attitudes towards armed conflict risk into selection of protected areas for conservation. Nature Communications, 7, 10.

Khagram, S., \& Ali, S. (2006). Environment and security. Annual Review of Environment and Resources, 31, 395411. doi:10.1146/annurev.energy.31.042605.134901

Kharel, F. R., Bhatta, S. R., \& Shah, K. B. (2012). Community engagement in the protected area management in Nepal. Biodiversity conservation in Nepal: A success story (pp. 21-30). Department of National Parks and Wildlife Conservation, Babar Mahal, Kathmandu. Retrieved from https://www.researchgate.net/publication/272354436_biodiversity_conservati on_in_nepal_a_success_story

Lee, M. (2006). Cree (Nehiyawak) teaching. Retrieved from www.fourdirectionsteachings.com/transcripts/cree.pdf

Lunstrum, E. (2014). Green militarization: Anti-poaching efforts and the spatial contours of Kruger National Park. Annals of the Association of American Geographers, 104(4), 816-832. doi:10.1080/00045608.2014.912545

Marijnen, E., \& Verweijen, J. (2016). Selling green militarization: The discursive (re)production of militarized conservation in the Virunga National Park, Democratic Republic of the Congo. Geoforum, 75, 274-285. doi:10.1016/j.geoforum.2016.08.003

Marijnen, E. (2017). The 'green militarisation' of development aid: The European Commission and the Virunga National Park, DR Congo. Third World Quarterly, 38(7), 1566-1582. doi:10.1080/01436597.2017.1282815

Martin, E. B. (2006). Policies that work for rhino conservation in West Bengal. Pachyderm, 41, 74-84. Retrieved from http://www.rhinoresourcecenter.com/pdf_files/119/1194081646.pdf

Munro, A. (2013). State monopoly on violence. Retrieved from https://www.britannica.com/topic/state-monopolyon-violence

Native American Medicine Wheel. (n.d.). Retrieved 22 February 2018 from http://medicinewheel.com/

Singh, S. S. (2015, March 12). Rhino numbers rise in West Bengal. The Hindu. Retrieved from http://www.thehindu.com/todays-paper/tp-national/rhino-numbers-rise-in-west-bengal/art icle6988082.ece\#!

Thapa, K., Nepal, S., Thapa, G., Bhatta, S. R., \& Wikramanayake, E. (2013). Past, present and future conservation of the greater one-horned rhinoceros Rhinoceros unicornis in Nepal. Oryk, 47(3), 345-351. Retrieved from https://www.researchgate.net/publication/258937313_Past_present_and_future_conservation_of_the_greate r_one-horned_rhinoceros_Rhinoceros_unicornis_in_Nepal. 
Wenger-Nabigon, A. (2010). The Cree medicine wheel as an organizing paradigm of theories of human development. Native Social Work Journal, 7, 139-161. 
